\title{
INFLUENCE OF THE USE OF WHATSAPP SOCIAL MEDIA ON THE RESULTS OF LEARNING GERMAN OF STUDENTS OF SMA NEGERI 20 MALUKU TENGAH
}

\author{
Cecilia Meideline Pattiselanno, Juliaans E.R. Marantika. G. H. Kunu \\ Pattimura University, German Language Education Study Program \\ Email: Julians.marantika@yahoo.com
}

\begin{abstract}
This research aims to explain the influence of whatsApp's use of social media as a learning medium on german learning outcomes. This study has two variables, namely the use of WhatsApp social media as a learning medium $(\mathrm{X})$ as a free variable and german learning outcomes as bound variables (Y). The method used in this study is Ex Post Facto. This research data is obtained through interviews, questionnaires and results of learning German odd semesters (Midterms and End Semester Exams) through documentation studies. WhatsApp social media as a learning medium is used through interviews with teachers and questionnaires given to German learners. The data of the questionnaire results is processed with a likert scale then analyzed using percentage descriptive analysis techniques, then the results of German learning are processed with the T-Test technique. The results of the German language learning process showed that the use of Whatsapp social media as a learning medium had a positive effect on german learning outcomes.
\end{abstract}

Kata Kunci : Social Media, learning media, Whatsapp, learning outcomes

\section{Introduction}

The era of revolution 4.0 or better known as the Digital Era, is characterized by the development of communication technology in all areas of life. The development in question can be seen in the many uses of gadgets (Mobile Phone) and internet networks that facilitate the process of long-distance communication. The development of information technology also penetrates the world of education and is used as a support for the learning process. As Wekke and Hamid put it in Khusniyah \& Hakim (2019:20). Information technology can be accepted as a medium in carrying out the educational process, including assisting the teaching and learning process, which also involves finding references and sources of information.

Changes in learning activities in the network due to learning policies from home, implemented so quickly that preparation in the face of these changes is not maximal and becomes a new thing for teachers and students in adjusting learning. One of the right steps in dealing with this situation is to utilize advances in network and information technology to support the effectiveness and efficiency of learning systems in schools. There are several online media that are used today as a means of 
online learning communication, for example: Zoom, Google Classroom, Webblog, Google, Youtube, Edmodo and others.

Learning outcomes are an image of students' learning achievement from the learning process that is carried out in accordance with their level. Students' learning outcomes will be good depending on the treatment of the learning process which is considered as one of the giving of learning experiences. (Hamalik in Sulastri, and friends $2015: 92$ ), Learning outcomes are evidence that a person has learned and that there have been behavioral changes in that person, for example from not knowing to knowing, and from not understanding to understanding. Cedefop (2014) (in Salamony, and friends 2021), said that " Bei Lernergebnissen handelt es sich um Wissen, Fähigkeiten und Kompetenzen, die am Ende des formalen, non-formalen Lernprozesses von den Lernenden demonstriert werden können ". Which means that learning outcomes are knowledge, skills and competencies that can be shown by learners at the end of the learning process both formal and non-formal. Djamarah 2007 (in Maisaroh, and friends 2010:161), said that Learning outcomes are the achievements of an activity that has been done, created, both individually and in a team. Furthermore Wahidmuri 2010 (in Litualy and Waremra 2018:13), explained that a person can be said to have succeeded in learning if he is able to show a change in himself. These changes include in terms of his thinking ability, skills or attitude towards an object. Arikunto 2015 (quoted by Apituley \& Tuhumury 2018: 36), reveals learning outcomes as the final result after experiencing the learning process, the change appears in actions that can be observed and measured. As also stated by Europäische Gemainschaften (2009) (in Reinhard Zürcher 2012 : 12), “ Lernergebnisse beschreiben, was die Lernenden nach dem erfolgreichen Abschluss eines Lernprozess wissen, verstehen, bzw können sollten “. This means that learning outcomes describe what students know, understand or can do after successful completion of a learning process. In line with that Nasution (in Lestari: 117), explained that learning outcomes are a change that occurs in individuals who learn, not only changes in knowledge but also shape skills in the personal learners.

The word media comes from the Latin medius means 'middle', 'intermediate', or 'introduction'. While in Arabic media means intermediary or delivery of messages from sender to recipient of the message. Thus, it can be said that the media is a tool that serves as a delivery message from the sender to the recipient. According to Basyarudin 2002 (in Tafonao 2018:105), Media is all forms used for the process of distributing information. AECT (Association of Education and Comunication Technology) describes media as all forms and channels used to convey messages or information. Furthermore, the NEA (National Education Association) argues that the media is a variety of objects that are manipulated so that they can be seen, heard read or talked about along with the instruments used for these activities. Koyo, and friends (in Sukiman 2012: 28). According to Heinich, and friends (in Arsyad 2019: 3) Media is an intermediary that transports information between the source and the recipient. So, television, film, photos, radio, audio recordings, projected images and the like are 
communication media and if there are messages in the form of information that contains teaching purposes then the media is referred to as a medium of learning. Along with the development of the times came various new breakthroughs from media that are used as a means of online communication in the world of education. One of them is media in the form of applications and sites that involve internet-based technology or commonly called social media. Andreas Kaplan \& Michael Haelein (in Ma'mun 2015:15) explained that social media is a group of internet-based applications created on the basis of the ideology and technology of web 2.0, and which enable the creation and exchange of user-generated content. Nasrullah 2015 (in Widada 2018: 24) said that social media is a medium on the internet that allows users to present themselves or interact, work together, share, communicate with other users and form social bonds virtually.

Social media is usually used as a media to communicate and socialize or is also usually used as a means of entertainment such as playing online games or just looking at photos and videos. Ellison 2007 (in Triastuti, and friends 2017: 17) argues that most social media sites can help people to be able to communicate, get to know, and be able to connect with others based on the same interests, in addition everyone can communicate by utilizing features contained on social media such as chat features where people can send private messages, comment on available columns and can share photos and videos., Zứniga 2012 (in Triastuti and friends 2017 :17). Abidah (2020:10) explained that, one of the potentials of technology that can be utilized as a learning medium is the use of smartphones and the internet, the combination of these technologies creates instant messaging services such as Whatsapp. Furthermore, it is said that Whatsapp is a social media application to deliver instant messages that use a $4 \mathrm{G}, 3 \mathrm{G}$ or Wifi internet connection without additional costs other than internet data connection fees.

Furthermore Hartono 2012 (in Afnibar, et al 2020: 72) explained that whatsapp is a cross-platform messaging application that allows its users to send messages without SMS fees, because whatsapp uses the same internet data package for email, browsing, web and others. As quoted in www.praxitipps. chop.de'“'Whatsapp ist ein Messenger, mit dem Sie über Ihre Internetverbindung am Smartphone mit anderen Nutzern chatten oder sogar telefonieren ". The following are some of the features owned by Whatsapp social media according to Rusni 2018 (in Andjani, et al 2018: 43), among others: a) sending text messages; b) receive and send photos from live cameras or albums and send videos; d) exchange documents in the form of files or others; e) make phone calls and video calls or send voice recordings directly; f) share location by utilizing GPS; g) Sending a contact card; h) exchanging emoticons and stickers through personal chat (PC) or Group chat (GC); i) can change profiles, status posts, back up messages, change numbers and maintain account security and set privacy in using whatsapp in the settings feature.

Abidah (2020: 10), said that in learning using whatsapp, the material delivered in the form of digital practical on mobile phones can awaken the motivation 
of learners in learning so as to improve learning outcomes. Furthermore Pustikayasa 2019 (in Ratnasari 2020: 132) proposed some of the advantages of using whatsapp social media as a learning medium are: 1) Whatsapp groups, educators and learners can ask answers or discuss more relaxed without having to focus on educators such as learning that occurs in the classroom, which often causes fear of wrong and embarrassment in learners, 2) With whatsapp educators can be creative in providing additional materials and tasks to learners, 3) Learners can easily send back tasks done either in the form of direct comments (chat groups), images, videos or soft files related to learning, 4) With Whatsapp media, the learning process becomes environmentally friendly, because it no longer uses hardcoppy (the use of paper to print or write the work of learners), 5) Can be one of the educators' solutions to convey additional material as learning materials outside the classroom.

The advantages and disadvantages of Whatsapp, delivered by Saragih, et al (2020: 209). First, the advantages of whatsapp are, not as wasteful quotas as other social media applications, facilitating learning during the Covid-19 pandemic. Second, through whatsapp meteri group delivered by teachers can be accessed easily by all students, furthermore, discussions can be held about the subject matter. In contrast, the shortcomings of Whatsapp are: (1) weak networks make it difficult to download material delivered by teachers, (2) many incoming messages result in mobile phones being slow, and (3) individual assessment tests sent through groups, so that students who have not done the task, can cheat the results of their friends' work.Based on some of the opinions above, it can be concluded that Whatsapp social media is one of the media that allows users to be able to exchange messages, and can be used as a means of communication in the learning process. Thus, the purpose of this study is to find out whether there is an influence on the use of WhatsApp social media as a learning medium on students' German learning outcomes.

\section{Research Method}

The research method used is ex post facto research, where the nature of this study does not give treatment or manipulation because free variables have already occurred. According to Sudjana \& Ibrahim (in Lingga 2016: 41), ex post facto as a research method refers to the treatment or manipulation of $\mathrm{X}$-free variables has occurred before, so that researchers do not need to do treatment anymore, just look at the effect on variables bound Y. Ex post facto in this study is the fact that shows that teachers and students have used whatsapp social media as a learning medium. There are two variables in this study, among others: (1). Free Variable: Whatsapp social media (2). Bound Variables: German Learning Outcomes. The instruments used in this study are: Documentation studies to collect the value of German learning outcomes before using Whatsapp social media as a learning medium and after using Whatsapp as a learning medium, then interviews and questionnaires as instruments to conduct initial studies used to reveal data regarding the use of Whatsapp social media as a learning medium. Data analysis techniques in this study will be used descriptive statistics and inferential statistics. Descriptive statistics are used to describe research variables in the form of visualizations in the form of tables or percentage charts of 
respondents' answers to problem indicators (Ali, 1993: 186). Inferential statistics are used to test proposed hypotheses. Hypothesis testing will be done using the t-test to see how much difference the results of learning German before using Whatsapp as a learning medium and after using Whatsapp as a learning medium.

\section{The Result of the Research}

In this study analyzed data on german learning results of students in grade XI of SMA Negeri 20 Maluku Tengah before using Whatsapp as a medium of learning and their learning outcomes after using whatsapp. The data is collected from the value of midterm test results which is the value before the use of Whatsapp as a medium of learning and end-of-semester test scores after the use of Whatsapp as a learning medium. The study was held in the odd semester, the 2020/2021 school year. Based on the data obtained, it is seen that there is a significant difference from the student's learning outcomes. Data on german learning results of students in grade XI SMA Negeri 20, with the number of respondents $=30$ students, before applying the use of Whatsapp in learning, the lowest score is $60=1$ person, while the highest score is $78=3$ people from a maximum score of 100 . Conversely, after the application of Whatsapp as a learning medium, obtained the following results: the lowest score $=75$ as many as 2 people and the highest score $=97$ as many as 1 person. The hypothesis of this study is that there is an influence on the use of Whatsapp social media on the results of learning German high school students in SMA Negeri 20 Maluku Tengah ". The formulation of the hypothesis will be proven by the calculation of the t-dependent test. The proofing criterion of the hypothesis is that the hypothesis $\left(\mathrm{H}_{1}\right)$ will be accepted, if the thit value is greater than the value of the ttab. On the other hand, the hypothesis $\left(\mathrm{H}_{0}\right)$ will be rejected if the thit value is less than the ttab value.

The results of the data analysis with the t-test, showed that the value of $\mathrm{t}_{\text {count }}=$ 20.9. This value is compared to $t_{t a b}$ at the level of belief $\alpha 0.05$ and the degree of freedom $=29$ obtained $t_{\text {tab }}=2.75$. Thus the results obtained show that $t_{\text {count }}>t_{\text {tab }}\left(t_{\text {count }}\right.$ $\left.=20.9>\mathrm{t}_{\mathrm{tab}}=2.75\right)$. The results of these calculations illustrate that ( $\mathrm{t}_{\text {count }}$ is greater than $t_{\text {tab. }} \mathrm{H}_{0}$ was rejected and $\mathrm{H}_{1}$ accepted. This means that there is a significant influence on whatsapp social media use on students' German learning outcomes.

\section{Discussion}

Based on the results of the calculations above, it can be seen that the results of learning German students through hypothesis testing with t-test analysis techniques show a significant difference between learning outcomes before the application of Whatsapp and after the application of Whatsapp. As proof is the tcount value of 20.9 $>t_{\text {tab }}$ 2.04). Thus it can be said that the use of whatsapp as a learning medium proved effective in improving students' learning outcomes in German language learning.

The results of the above data analysis were supported by interviews with German language teacher and questionnaires to 30 students who were respondents in the study. The results showed that most students gave a positive response to the use 
of Whatsapp social media as a learning medium with a percentage (72.61\%). Furthermore, students' knowledge of Whatsapp social media, showed excellent categories $(83.47 \%)$. This means that students have understood the use of whatsapp social media. In other words, this medium is already quite popular among students. Furthermore, students' knowledge of the features on Whatsapp is as large as $(71.86 \%)$. These whatsapp features have been utilized and used well by students in the teaching and learning process. WhatsApp also provides a fun learning experience for students in learning. With the use of Whatsapp, students can learn anytime and anywhere. The learning process with whatsapp seems more relaxed and rilex than face-to-face learning in the classroom, because it turns out that whatsapp is more practical in its use, in addition, through whatsapp media, students can learn independently. This is evidenced by the student's good response of (74.02\%). The obstacle in learning by using Whatsapp is the quality of the internet network, which is sometimes less stable. As evidence is the student's response regarding network conditions, with sufficient categories $(58.33 \%)$. From these results it can be said that students are quite skilled in using Whatsapp social media as a learning medium one of the factors that becomes an obstacle in its use is about network stability. But regardless, both students and teachers realize that there are benefits of using Whatsapp social media as a medium of learning German. This is evident through interviews conducted with teachers that Whatsapp can make it easier for teachers in terms of delivering subject matter for those sent through existing features such as document sharing media in the form of files (word, powerpoint) or meteri downloaded via Youtube then shared to Whatsapp, or even teachers can combine learning using voicenote features, call/videocall to discuss with students.

Learning by using whatsapp social media also leads students to learn more independently and with the convenience available through the features on whatsapp social media students become more active in the learning process, where they no longer become afraid to do face-to-face with teachers who sometimes make them embarrassed in their opinions. So that it can have a good impact on students' learning outcomes.

\section{Conclusion}

Based on the results of the data analysis, can be concluded that Whatsapp is one of the good social media used as a learning medium in improving german learning outcomes, especially in the learning process that takes place online. What has been proven through the calculation of t-test is thit $20.9>\operatorname{ttab} 2.04$, the results of the questionnaire data of $72.61 \%$ belong to the category of good and positive response of teachers obtained from the results of the interview.

\section{References}

Afnibar, dkk, 2020. "Pemanfaatan Whatsapp Sebagai Media Komunikasi Antara

Dosen dan Mahasiswa dalam Menunjang Kegiatan Belajar (studi terhadap 
mahasiswa UIN Imam Bonjol Padang”. Jurnal Komunikasi dan Penyiaran

Islam. Vol 11, No 1, P-ISSN :2086-1303, E-ISSN : 2657-0521

Ahriana, dkk. "Studi Analisis hubungan antara Self Efficacy dengan Hasil Belajar

Fisika Siswa Kelas XI MIA SMA Negeri 1 Takalar”. Jurnal Pendidikan

Fisika. Vol 4, No 2, ISSN : 2302-8939

Abidah, 2020. "Peran Aplikasi WA Sebagai Media Pembelajaran dalam Mata kuliah

Metodologi Penelitian”. BIDAYAH. Vol 11, No.1, ISSN: 2085-2541

Aspari, 2016. " Media Sosial Sebagai Media Pembelajaran Bahasa Pada Masyarakat

Modern”.Simposium Nasional Ilmu Pengetahuan dan Teknologi. ISBN:

978-602-61268-0-1

Arsyad, 2019. Media Pembelajaran. Depok:Rajawali pres,xvi,244 hlm,233.

Apituley, Tuhumury, 2018. "Pengaruh Penggunaan Model Pembelajaran Quantum

Teaching terhadap hasil belajar bahasa jerman siswa SMA Negeri 1

Ambon".Jurnal Tahuri Vol 15, No.1

Angreni, dkk,2017.'Ketersediaan dan pemanfatan media komponen instrumen ter-

padu (KIT) IPA di sd Negeri Kecamatan Nanggalo Kota Padang ”.Jurnal

Pendidikan Pendidikan Dasar Nusantara. Vol 2, No 2.ISSN : 2460-6324

Andjani, dkk, 2018. "Penggunaan media komunikasi Whatsapp terhadap Efektivitas

Kinerja Karyawan”.Jurnal Komunikatio Vol 4 No.1

Hakim, 2013. "Ulasan Metodologi Kualitatif :Wawancara terhadap Elit". Wawasan

Metodologi Kualitatif“. Jurnal.dpr.go.id.Diakses pada 27 february.2020.

Khusniyah, Hakim, 2019."Efektivitas Pembelajaran Berbasis Daring: Bukti Pembe-

lajaran Bahasa Inggris“.Jurnal Tatsqif.Vol 17.No.1 ISSN: 2503-4510

Jakni, 2016." Metodologi Penelitian Experimen Bidang Pendidikan“. Alfabeta :

Bandung Sta77 (xii + 328). ISBN : 978-602-289-224-3

Litualy, S.J and Waremra, 2018. "Model Pembelajaran Group Investigation dan Hasil

Belajar Bahasa Jerman Siswa SMA PGRI-1 AMBON”. Jurnal Tahuri. Vol 15, No. 1

Lestari. “Pengaruh Belajar dan Minat Belajar Terhadap Hasil belajar Matematika”. Jurnal Formatif. Vol 3, No.2, ISSN:2088-351X

Lingga Masriati,2016."Pengaruh Penggunaan Media Pembelajaran Quipper School

Terhadap Hasil Belajar Siswa Kelas VIII Mata Pelajaran Matematika SMP Negeri 4 Semarang”. Skripsi

Maisaroh, dkk, 2010. "Peningkatan hasil belajar siswa dengan menggunakan metode Pembelajaran Active Learning Tipe Quiz Team Pada Mata Pelajaran Keterampilan dasar Komunikasi di SMK Negeri 1 Bogor”. Jurnal Ekonomi \& Pendidikan, Vol 8. No 2.

Ma'mun,2015. "Efektivitas pembelajaran bahasa arab melalui media sosial Whatsapp di program BISA (belajar islam dan Bahasa arab)". Skripsi.1-74

Ratnasari, 2020. "Penerapan Aplikasi Whatsapp terhadap Minat dan Prestasi Peserta didik".Jes-Mat, Vol 6, No. 2,129-138. 
Raresik, 2016. “Analisis Faktor yang mempengaruhi hasil belajar Bahasa Indonesia pada siswa kelas V SD Gugus VI'.e-journal pgsd Universitas Pendidikan Ganesha.Vol 4, No. 1

Raharti, 2019. "Whatsapp Media Komunikasi Efektif Masa Kini”.Visi Pustaka, Vol 21, No 2.

Sulastri dkk, 2015. "Meningkatkan Hasil Belajar Siswa Melalui Strategi Pembelajaran Berbasis Masalah pada Mata Pelajaran IPS di kelas V SDN 2 Limbo Makmur Kecamatan Bumi Raya”. Jurnal kreatif tadulako Online. Vol 3, No.1, ISSN 2354-614X.

Salamony dkk , 2021.“ Model Pembelajaran Pair Checks dan Hasil Belajar Bahasa Jerman Siswa SMA Negeri 1 Ambon“. Jurnal Erfolgereicher Deutchunterricht. Vol 1, No 1, e-ISSN : 2775-4685

Saragih, dkk, 2020. "Efektivitas Penggunaan Whatsapp Group Selama Pandemi Covid-19 Bagi Pelaku Pendidik". Proseding seminar Nasional Multidisiplin ilmu Universitas Asahan ke-4. agethaevasaragih@gmail.com

Sukiman, 2012.Pengembangan Media Pembelajaran. Depok:PT Pustaka Insan Madani, Anggota IKAPI

Suryani, 2017. "Fungsi Whatsapp Grup Shalihah Cabang Bandar Lampung Sebagai Pengembangan Media Dakwah Dalam Membentuk Akhlakul Karimah

Sunarsi denok, 2017. "Pengaruh Gaya Kepemimpinan dan disiplin Kerja terhadap Kinerja Kerja Karyawan pada CV. Usaha Mandiri Jakarta”. Jurnal ilmiah management sumber daya manusia Jenius, Vol 1 (2), 1-24

Syahrum,dkk, 2012. Metodologi Penelitian Kuantitatif. Ciptapustaka Media. Jl Cisitu Lama III No 24 A Bandung 40135. ISBN 979-3216-90-5

Sahidillah W.M,dkk, 2019. "Whatsapp Sebagai Media Literasi Digital Siswa". Varia Pendidikan,vol 31. No 1, ISSN :0852-0976

Triastuti,dkk, 2017. "Kajian Dampak Penggunaan Media Sosial Bagi Anak dan Remaja”. No. 15, ISBN 978-602-73963-2-6

Tafonao, 2018. "Peran Media Pembelajaran dalam Meningkatkan Minat Belajar Mahasiswa". Jurnal Komunikasi Pendidikan, Vol 2. No 2 E-ISSN : 25494163, P-ISSN : 2549-1725

Widada, 2018.“Mengambil Manfaat Media Sosial Dalam Pengembangan Layanan Journal of Ducumentation and information Science Vol 2 No.1,-ISSN 2502-6003

Yensy, 2020. “ Efektivitas Pembelajaran Statistika Matematika Melalui Media Whatsapp Group Ditinjau dari Hasil Belajar Mahasiswa (Masa Pandemik Covid-19)". Jurnal Pendidikan Matematika Raflesia. Vol 05, No. 02. PISSN : 2548-4435, E- ISSN : 2615-8752

Zürcher Reinhard, 2012. "Lernergebniddorientierung in der Erwachsenenbildung“'bm:uk : Bundesministerium für Unterricht, Kunst und Kultur. Wein : Minoritenplatz 5. 